\title{
Developing reflective picture storybook media to improve students' tolerance in elementary schools
}

\author{
Rohmatul Ummah \& A. Mustadi \\ Faculty of Education: Dept. Elementary school of education \\ Universitas Negeri Yogyakarta \\ Yogyakarta, Indonesia \\ rahmaumayah@yahoo.co.id
}

\begin{abstract}
This this study aims to produce reflective picture storybook media and determine the effectiveness of the media to increase students' tolerance. This study was a developmental study based on 10 major steps developed by Borg \& Gall. The subject of the study was the fifth grade students' of elementary school. The data were collected using the interview guidelines, self reports, literature review, expert-validated questionnaire of the product, questionnaire of teachers and students' responses, as well as tolerance scale. The data were analyzed by paired sample t-test with $\alpha=0.05$. The result of the study was reflective picture storybook media. The developed media was considered appropriate by material experts with "very good" category. The students' tolerance in experiment class improved significantly according to t-test, with sig. (2-tailed) $=0,00$. By using this instructional media, the students can internalize tolerance in a fun learning and gain knowledge according to the curriculum
\end{abstract}

\section{Keywords-Story book media; tolerance; elementary school}

\section{INTRODUCTION}

Observing the multicultural condition in Indonesia, tolerance is important to avoid conflicts in the social life. Tolerance is characterized with the respect on different ethnic, gender, physical appearance, culture, religion, social belief, and ability [1]. Living together in harmony and democracy is expected [2]. Being objective in appraising something and understanding different arguments is required [3].

One of the ways to inculcate tolerance is through school. School provides learning space for students to comprehend role, rule, and hope in their interaction with friends and teachers [4]. Through the activities in school, students can learn about spiritual and religion, knowledge, how to socialize, and some other skills needed in social life. Teacher becomes an important element in designing and implementing school activities. Students are guided through objective sample [5]. As an example, in presenting the material related to history of Islamic Kingdom in Indonesia, it is impossible to go back to the past as well as to go to the museum as it needs huge cost. Yet through reading literature about the historical story will be more feasible.

Reading can help children to learn while having fun. However, unfortunately, reading interest in Indonesian society is still low. Based on the study done by Most Littered Nation in the World in 2016, the reading interest in Indonesia was in 60th rank of 61 countries (http://www.tribunnews.com, 2017).
This fact is surely saddening considering there are much advantage we can get from reading. According to [6], children can see interesting illustration, know some good storyline, tend to be realistic, and laugh at funny things, which can stimulate them to be happy. Children will experience inner satisfaction that will be useful for their emotional development. In addition, reading can improve characters with plot of stories that might contain values of hard work, simplicity, tolerance, discipline, piety, honesty, humanity, and wisdom [1].

In addition to reading interest issue, the availability of story books intended to support the material of Islamic kingdom in Indonesia is still limited. Books sold in the market are more narrative than presenting plots, characterization, themes and moral values, background, illustration, as well as interesting format [7]. If historical story is created in more interesting way, the children will be able to express their feeling of fear, joy, sadness, and so on by the struggle of historical figure. A captivating figure can provide examples to be imitated in their everyday life. This is because role models can inspire an individual to have hope and achievement in the future $[6,7]$

One of the illustrated story developed is a reflective picture story book media. According to [8], one needs moral reflection so that they build the cognitive side of a character in which they are able to make a moral balance in their and others' behavior. This moral reflection is used to get students to comprehend the meaning of the stories they read in order to apply the values in their real life. This media include materials that are not only text-oriented, but also completed with illustrations. It is entitled "The History of Demak Bintoro Kingdom" and the story of "Beautiful Life with Tolerance" reflected from the figure in Demak Bintoro Kingdom.

The development of this media is based on the results of students' needs analysis through self-assessment conducted on the $5^{\text {th }}$ grade elementary school students in elementary school Bantul District. The results showed that the children's tolerance was not optimal. Approximately $72 \%$ or 48 of 67 students wrote themselves negatively such as being ignorant with relatives, quarrelling often, cheating, making the class crowded, irritable, rude, mocking, picking friend, etc. Then, the result of observation and interview with teacher showed that there was no tolerance characterization in the periodic program at school. In addition, there was no media that 
supported the task about playing the role of the Islamic Kingdom in Indonesia. While the books sold in bookstores are mostly in the form of novels that contain more narrative text than images so it takes a long time to read. Narration with no image gives less opportunity to students to imagine concretely [9].

The picture storybook contains interrelated images and texts $[9,10]$. Both are complementary to describe a story. The picture on the picture storybook provides an opportunity for children to imagine more effectively. Images help children to understand the content in a glance, in contrast to the writing that needs to be understood little by little[11]. By looking at the picture, the children will be guided to connect what is read with the illustrations in the reading.

Not all books are in the child-reading category. Reference by [12] stated that reading media should have a reflective principle or can provide feedback and help others to provide insights on social responsibility and etiquette that can later teach children to take action or contribute to society. A moralbased reflection is important to make one capable of making moral balance against their and others' behavior [1].

Then appeared reflective picture storybook which is a book that can represent curriculum materials and tolerance reflection. The reflective picture storybook contains five components: 1) pictorial story related to learning materials entitled "Demak Bintoro Kingdom", 2) reflective picture story entitled "Beautiful Life with Tolerance," 3) reflective questions, 4) reflective journals for conditioning the attitudes of students' everyday life, and 5) stories of self-change in the form of changes in student attitudes after reading this book. The purposes of the reflective picture storybook media are to be a medium containing the material determined and reflected in everyday life and to integrate the values of characters in it, to guide students to think deeply, and to give examples to students to behave according to tolerance.

The characteristics of the books should be covered several aspects related to the format of the book (image and text layout, appearance, suitability of size and shape, suitability of paper type, color, spacing, margin, object, cover and typeface), book content (suitability of theme and image, theme and texts, and images and texts), language (diction based on the difficulty level and complexity of the language structure as well as the beauty of the language presented in the book), and also considering media selection criteria as well as moral reflection criteria.

Then, how the reflective picture story book media are appropriate and effective to improve the tolerance of the $5^{\text {th }}$ grade elementary school students?

\section{METHOD}

This study implemented Research \& Development ( R \& D) model according to [13]. The data were collected through interviews, literature reviews, questionnaires, scale, and self report. The examined variables from reflective picture storybook including the format, content, language, media selection criteria and moral reflection criteria. Then the examined variables from tolerance include being fair to other, respecting other, helping, receiving the advice, cooperating, being friendly, appreciating difference, being open-minded, and opposing enmity.

The procedures of this study were:

1. Research and Information Collecting: Literature review \& Need Analysis.

2. Planning: mapping the lesson plan.

3. Developing preliminary product: developing \& validating the product

4. Preliminary Field Testing: analyzing questionnaire response of the media from 1 teacher and 6 students.

5. Main product revision: revising by analyzing questionnaire response of the preliminary field testing.

6. Main field testing: analyzing questionnaire response of the media from 1 teacher and 16 students.

7. Operational product revision: revising by analyzing questionnaire response of preliminary field testing

8. Operational product testing: testing product in 1 experiment class and 1 control class followed by analyzing data using t-testing

9. Final product revision : revising the result of operational product testing

10. Dissemination and Implementation: Disseminating product to teacher and headmaster in Bantul Sub-district.

A need analysis was conducted using interviews and self reports to know the implementation of character building and learning media as well as the student tolerance. A literature review was conducted by reviewing journals and book related to the picture storybook and tolerance. The product was reviewed by material and media experts with 34 items of questionnaires for media expert and 33 items for material experts. The analysis technique for tolerance scale used t-test with significance level of 0,05 . Subjects in this study were 58 students from 3 classes. If the sig ( 2 tail) value $<0.05$, then the reflective picture story book effectively improved the students' tolerance.

\section{RESULTS AND DISCUSSION}

This developmental study aims to develop a learning media product which is reflective picture storybook that has been feasible according to the material expert in the aspect of content, language, criteria of media selection and criteria of moral reflection. According to the media expert, it is feasible in the aspect of the format as well. The result of the expert validation questionnaire by material expert is shown in table 1 .

TABLE 1. The Result of The Validation by Material Expert

\begin{tabular}{|c|c|c|c|c|c|}
\hline No. & Questionnaire & Value & Items & $\begin{array}{c}\text { Max. } \\
\text { score }\end{array}$ & Category \\
\hline 1. & Content & 75 & 18 & 90 & Good \\
\hline
\end{tabular}




\begin{tabular}{|c|c|c|c|c|c|}
\hline 2. & Language & 12 & 3 & 15 & Good \\
\hline 3. & $\begin{array}{c}\text { Media selection } \\
\text { criteria }\end{array}$ & 24 & 6 & 30 & Good \\
\hline 4. & $\begin{array}{c}\text { Moral reflection } \\
\text { criteria }\end{array}$ & 24 & 6 & 30 & Good \\
\hline & Total & 135 & 33 & 165 & Good \\
\hline
\end{tabular}

Then, the result of the expert validation questionnaire by media's expert is shown in table 2 .

Table 2. The Result of The Validation by Media's Expert

\begin{tabular}{|c|c|c|c|c|}
\hline Questionnaire & Value & Items & $\begin{array}{c}\text { Max. } \\
\text { score }\end{array}$ & Category \\
\hline Format & 167 & 34 & 170 & Very good \\
\hline
\end{tabular}

The reflective picture storybook produced is about the story of Demak Bintoro Kingdom and the story of reflection on Beautiful Life with tolerance used as one of the supporting books for the $5^{\text {th }}$ grade students on the theme 7 and sub-theme 1 "The Kingdom of Islam in Indonesia".

Based on the operational test in February 2017 at Elementary School 1 Bantul, the produced media was claimed effective to increase the character of tolerance. The result of the 2-tail t-test showed sig. $(0,00)<0.05$ so it was considered that the experimental class had higher tolerance character value than the control class (Ho accepted). Thus, this medium effectively increases students' tolerance. Calculation results could be seen in table 3 .

Table 3. The summary of post-test t-test scale of tolerance in the experimental class on control class

\begin{tabular}{|c|c|c|}
\hline Data Type & $\begin{array}{c}\text { Sig } \\
(\mathbf{2} \text {-tail })\end{array}$ & Conclusion \\
\hline $\begin{array}{c}\text { Post test Scale Data for } \\
\text { Experimental Class with } \\
\text { Control Class }\end{array}$ & 0,00 & $\begin{array}{c}\text { Experimental Class is } \\
\text { higher than control } \\
\text { class }\end{array}$ \\
\hline
\end{tabular}

The sections in this book are as follows. First, the story of Demak Bintoro Kingdom which presents about Demak Bintoro Kingdom. The characters in this story are Princess Campa, King Brawijaya V, Raden Patah, Raden Kusen, Sultan Trenggana, Adipati Yunus, Sunan Ampel, the robber, the Portuguese as colonists, and the assassin of Sultan Trenggana. The storyline is dramatized so it stimulates emotions to be sad, confused, happy or angry. The illustrations in this book use interesting cartoons. The message delivered in this story is related to respecting the religious differences Raden Patah has with his father, never giving up in studying, being obedient to the parents and being courageous to expand the country.

Second, the story of Beautiful Life with Tolerance. This story is related to students' life. Characters presented are from the surroundings inspired by the moral value that exists in the Demak Kingdom Kingdom Story. The characters are Mother,
Father, Rahma, Tiara, Mae, Class Master, etc. Illustrations are cartoons. The values conveyed are the importance of doing good to friends, respecting others' religion, and asking for something with courtesy.

Third, reflective questions that guide students to assess their moral and also solve a problem reflected in the story. Fourth, reflective journal for self-assessment during 6-day meeting. This reflective journal is a self-regulated checklist to get students behave according to certain tolerance characters. According to [14], self-regulation can be done with 3 phases covering forethought, controlled behavior, and self-reflection. This forethought is the phase in which children in the setting matches with the expected tolerance behavior. Furthermore, the students' behavior is controlled (performance control phase) by filling in self-regulatory checklist.

Then, fifth, the story of self reflection arises after the behavior occurred, then people respond to it. Students can give an impression on activities that have been controlled by the teacher through stories of students' self-change. This story deals with changing the character of tolerance at home, school and community after reading the reflective picture storybook.

Based on first story, students and teachers could perform a drama in addition to reading the story. In this activity, students learned to tolerate others directly. Classes were divided into 2 groups, each of which was required to present the drama. Group A would share the drama equipment with group B whose members forgot to bring the equipment, while group B listened to group A that was performing enthusiastically. Similarly, when group A performing, group B listened well. Thus, the media reflective picture storybook provided space for students to implement tolerance right away not only knowing the concept of it and having the desire to do it.

In addition, there are students who came from the descendants of Irian Jaya who was quiet because he is often mocked by his friend. But with this fun activity, the child became more active in the classroom. Fun activity is one of several things that make students get to know others and the class remains fun with differences.

After reading this book, students were expected to be able to imitate good characters and avoid evil characters. The children took pictures of the Demak Bintoro Kingdom and the figure in Beautiful Life with Tolerance. Children related the stories in the book with their experiences and hopes. Reflection responded not only to the others' behavior but also to the conceptions in which the students believe, feel, hope, plan, and so on [15]. The response presented was explained in the answer to the reflection question. Reflection questions gave students the opportunity to think critically about the reading they have read.

\section{CONCLUSION}

The development of reflective picture storybook media was appropriate and effective to improve the tolerance of the $5^{\text {th }}$ grade elementary school students. This section of the book consists of the historical story of the Demak Bintoro Kingdom, the stories of Beautiful Life with Tolerance, reflective questions, reflective journals and stories of self reflection. By using this book, students did not just understand 
and want to be a good person, but also practised to do good things, gain knowledge about Demak Bintoro Kingdom, learn in fun activity and to be tolerant at home, school and society as well as to think critically about the reading they have read. This book is only used to support learning activities, teachers are expected to keep using the 2013 curriculum textbook in teaching learning activities.

\section{REFERENCES}

[1] R. S. Kipp, Dissociated identities: Ethnicity, religion, and class in an Indonesian society: University of Michigan Press, 1996.

[2] A. Giddens, The third way: The renewal of social democracy: John Wiley \& Sons, 2013.

[3] P. L. Strukel, "Instructional Design: How Secondary Teachers Promote Student Comprehension of Informational Text," Minnesota State University, Mankato, 2018.

[4] J. E. Brophy and T. L. Good, Teacher-student relationships: Causes and consequences: Holt, Rinehart \& Winston, 1974.

[5] D. P. Kauchak and P. D. Eggen, "Learning and teaching," New York: Allyn Bacon, 1993.
[6] J. R. R. Tolkien, On fairy-stories: Oxford University Press, 1947.

[7] L. Galda, L. A. Liang, and B. E. Cullinan, Literature and the child: Cengage Learning, 2016.

[8] M. W. Berkowitz, "The science of character education," Bringing in a new era in character education, pp. 43-63, 2002.

[9] J. Bruner, "Life as narrative," Social research, pp. 691710, 2004.

[10] R. N. Carney and J. R. Levin, "Pictorial illustrations still improve students' learning from text," Educational psychology review, vol. 14, pp. 5-26, 2002.

[11] D. J. Siegel and M. Hartzell, Parenting from the inside out: How a deeper self-understanding can help you raise children who thrive: TarcherPerigee, 2013.

[12] P. C. Blumenfeld, E. Soloway, R. W. Marx, J. S. Krajcik, M. Guzdial, and A. Palincsar, "Motivating project-based learning: Sustaining the doing, supporting the learning," Educational psychologist, vol. 26, pp. 369-398, 1991.

[13] W. R. Borg and M. D. Gall, Instructor's Manual for Educational Research: To Accompany Educational Research: an Introduction: Longman, 1983.

[14] M. Boekaerts, M. Zeidner, and P. R. Pintrich, Handbook of self-regulation: Elsevier, 1999.

[15] E. E. Jones and R. E. Nisbett, "The actor and the observer: Divergent perceptions of the causes of behavior," 1971. 